\title{
Sobre a Padronização de um Método Prático Para a Dosagem da Cafeína
}

\author{
Nilton E. Bührer \\ Instituto de Biologia e Pesquisas Tecnológicas
}

\begin{abstract}
In this work the author puts in evidence a practical and at the same time rapid method for the determination of the cafein quantity in erva-mate, that may be utilized to perfection in food and industrial analyses or others that not demand scientific rigour. The author presents a description of the method and makes a comparison with the classical method of Grandval-Lajoux, showing that the differences between the one and the other are practically nil. In conclusion, the result of the three analyses of the same sample of erva-mate, made by the Grandval-Lajoux method are cited, show that the same differences appear as those shown between the rapid method suggested by the author and the classical method. In this case, the maximum difference was 0,06\% and the minimum 0,01\%.
\end{abstract}

Key Words: Caffeine; Erva-mate; caffeine assay

\section{INTRODUÇÃO}

Existem vários métodos para a dosagem da cafeína em nosso mate, café, etc.; aliás são métodos citados por várias literaturas estrangeiras e nacionais, largamente utilizados entre nós.

Entretanto, o teor de cafeína encontrado, segundo o método empregado, é variável, o que é natural, pois todos eles possuem defeitos. Uns em virtude da dissolução de matérias estranhas, que continuam solubilizadas no solvente utilizado; outros, pela incompleta extração da cafeína do material a analisar, e finalmente outros, pela morosidade do processo.

Não citaremos aqui quais esses métodos e detalhes desses defeitos; o escopo principal deste relato, é a sugestão para que no Brasil se padronize um método rápido e ao mesmo tempo praticamente exato, para que os resultados comparativos de diversas análises efetuadas por vários técnicos, possuam valor interpretativo.

Referimo-nos a um método rápido e não menos eficiente que é utilizado por muitos analistas, e que não necessita de aparelhagem muito variada.

Em nosso laboratório do Instituto de Biologia, no Paraná e mesmo em aulas práticas ministradas a alunos, procuramos sempre por em evidência esse método, comparando-o com o clássico de Grandval-Lajoux que utiliza o extrator de Soxhlet. Conforme adiante será citado, o método rápido por nós utilizado, e que já é de conhecimento de muitos técnicos e de aplicação muito generalizada por outros em tempos anteriores, deu sempre resultados satisfatórios.

Procuramos pô-lo em prática em virtude de grande número de análises que tínhamos de efetuar, certa vez que foi-nos dada a tarefa de realizar um levantamento sobre os teores em cafeína das diversas ervas-mates de nosso Estado.

\footnotetext{
${ }^{\wp}$ Artigo publicado no Arquivos de Biologia e Tecnologia, v. 1, pp. 177-180, 1946.
} 
Vejamos a seguir, o método rápido utilizado:

- Pesar exatamente $2 \mathrm{~g}$ de erva-mate seca (100$\left.150^{\circ} \mathrm{C}\right)$, colocando-a em um becher $\left(\mathrm{de} 250 \mathrm{~cm}^{3}\right)$; adicionar $5 \mathrm{~cm}^{3}$ de $\mathrm{H}^{2} \mathrm{SO}^{4}$ conc. e levar ao banhomaria por 20 minutos (agitar o copo repetidamente para melhorar o contato do ácido com a erva).

Em seguida adicionar $50 \mathrm{~cm}^{3}$ de água destilada e ferver com aquecimento direto (Bunsen e tela de amianto) durante 10 minutos.

Filtrar em papel comum, lavando o copo com várias porções de água quente (pode ser levemente ácida). O filtrado total é levado a um funil de separação $\left(\right.$ de $500 \mathrm{~cm}^{3}$ ).neutralizar em seguida com amoníaco conc. até reação francamente alcalina (o líquido escurece); adicionar uns $60 \mathrm{~cm}^{3}$ de clorofórmio. Agitar suavemente para que os vapores do solvente, formados pelo contato com o líquido meio quente, escapem pela abertura. Em seguida arrolhar o funil, invertê-lo abrindo a torneira, e, conservando-a aberta, dar ao funil movimento circular para que a extração se processe.

Após dois minutos, fechar a torneira, colocar o funil em suporte (em posição normal) e deixar separar as camadas. Dar ao funil pequenos golpes, até destruir as bolhas de água que envolvem as gotas de clorofórmio (macro-emulsão). Separar a hipo-fase (camada inferior de clorofórmio), passando-a a um balão de destilação (para a devida recuperação); repetir a extração com mais duas porções de clorofórmio $\left(50 \mathrm{~cm}^{3}\right.$ de cada vez).

Os extratos reunidos no balão de destilação contém praticamente toda a cafeína dos dois gramas de erva.

Quando restar no balão cerca de $10 \mathrm{~cm}^{3}$ de clorofórmio, suspender a destilação, passar o solvente com a cafeína nele dissolvida para um cristalizador tarado (lavar uma vez o balão com o solvente recuperado, juntando-o ao cristalizador).

Evaporar o clorofórmio restante em banho-maria até secar, levar a uma estufa $\left(100-150^{\circ} \mathrm{C}\right)$, resfriar em dessecador e pesar.

$\mathrm{O}$ aumento do peso do cristalizador, multiplicado por 50 , nos dará a porcentagem de cafeína na erva seca.

Esse método, naturalmente adapta-se somente para análises comerciais; em se tratando de análises para fins científicos, é preferível adotar-se métodos mais exatos, embora de técnica mais demorada.

Afim de dar uma idéia da utilidade do método descrito, procuramos, por meio de análises comparativas com o método de Grandval-Lajoux, demonstrar as diferenças achadas, para uma mesma erva-mate, e também, as diferenças entre a mesma erva utilizando-se o mesmo método.

Há a acrescentar aqui o fato da amostragem das ervas, que nem sempre apresentam a mesma homogeneidade. A inclusão de pauzinhos, embora mínima, tende a diminuir a porcentagem de cafeína. A presença de pó de erva tem uma influência mínima, uma vez que se trate exclusivamente do pó de erva (e não outras impurezas comuns na mesma).

Portanto vejamos, como comparação, alguns dos muitos exemplos que poderíamos apresentar, sobre a comparatividade dos resultados:

\begin{tabular}{|c|c|c|c|}
\hline Amostras & Método utilizado & $\begin{array}{l}\text { Teor em } \\
\text { cafeína }\end{array}$ & diferença \\
\hline $\mathrm{N}^{\circ} 1$ & Grandval-Lajoux & $1,02 \%$ & $0,06 \%$ \\
\hline $\mathrm{N}^{\mathrm{o}} 1$ & Método sugerido & $1,08 \%$ & \\
\hline $\mathrm{N}^{\mathrm{o}} 2$ & Grandval-Lajoux & $0,95 \%$ & $0,04 \%$ \\
\hline $\mathrm{N}^{\mathrm{o}} 2$ & Método sugerido & $0,99 \%$ & \\
\hline $\mathrm{N}^{\circ} 3$ & Grandval-Lajoux & $0,88 \%$ & $0,04 \%$ \\
\hline $\mathrm{N}^{\mathrm{o}} 3$ & Método sugerido & $0,92 \%$ & \\
\hline $\mathrm{N}^{\circ} 4$ & Método sugerido (1) & $0,97 \%$ & $0,01 \%$ \\
\hline $\mathrm{N}^{\circ} 4$ & Método sugerido (2) & $0,98 \%$ & \\
\hline $\mathrm{N}^{\circ} 5$ & Método sugerido (1) & $0,92 \%$ & $0,05 \%$ \\
\hline $\mathrm{N}^{\circ} 5$ & Método sugerido (2) & $0,87 \%$ & $0,06 \%$ \\
\hline $\mathrm{N}^{\circ} 5$ & Método sugerido (3) & $0,93 \%$ & \\
\hline
\end{tabular}

Conforme deparamos na comparação acima, a maior diferença entre um método e outro foi de $0,06 \%$ e a mesma entre métodos repetidos (análises números 4 e 5).

A discrepância existente pode ser atribuída em grande parte, conforme já foi citada, à heterogeneidade das amostras.

Entre várias análises de uma mesma erva, efetuadas pelo método de Grandval-Lajoux, obtivemos, em um dos casos, os seguintes resultados:

\begin{tabular}{l|l|l}
\hline & & \\
Amostra $^{\circ}$ 11 & $(1)$ & $0,98 \%$ \\
Amostra n $\left.11^{\circ} 11\right)$ & $(2)$ & $0,97 \%$ \\
Amostra n $^{\circ} 11$ & $(3)$ & $1,03 \%$ \\
\hline
\end{tabular}

A diferença maior foi, nesse exemplo, também de $0,06 \%$.

Este último método (Grandval-Lajoux) sendo mais demorado e nos fornecendo, comparativamente 
resultados iguais ao outro, não justifica a sua aplicação em análises industriais, comerciais ou mesmo bromatológicas.

\section{OBSERVAÇÃO}

Quanto à qualidade da cafeína extraída, obtivemos muitas vezes belas agulhas brancas (quando a evaporação do clorofórmio é mais ou menos lenta). A ausência de corantes é quase completa. 